\title{
Duties \& Responsibilities of Notary Recipient of Minuta Deed of Notary Protocol who has Retired or has Passed Away in Salatiga
}

\author{
Nanda Kurniawan*) \\ *) Student Master of Notary Law, Faculty of Law, Universitas Islam Sultan Agung \\ Semarang
}

\begin{abstract}
This study aims to examine and analyze: 1) Duties and Responsibilities of Notaries as Recipients of the Minuta Deed Protocol. 2) Implementation and Submission of Protocols for Notaries Who Have Retired or Died in the City of Salatiga. The approach method used in this research is the empirical legal approach (sociological) because in this study it examines people in living relationships in society, the study uses empirical facts taken from human behavior, both verbal behavior obtained through interviews and real behavior done through direct observation. The specification is analytic descriptive research. Legal research is focused on examining the compliance of the community, especially notaries as recipients of duties and responsibilities of notaries as recipients of the Minuta Deed Protocol to a legal norm with the aim of measuring whether or not a legal arrangement is effective. In this study, the data source consisted of primary data obtained by researchers through interviews and secondary data obtained through literature studies. Based on the research results it can be concluded that: 1). 2) Constraints in Implementing Duties and Responsibilities of Notary Public as Recipient of Duties and Responsibilities of Notary Public as Recipient of Minuta Protocol, especially in Salatiga City, namely the lack of adequate and adequate space owned by the notary receiving the protocol, the number of protocols that must be accepted, it is not uncommon for the notary receiving protocol to lack a place to store due to limited office space. So it is better if you keep the minuta deed in the form of soft copy, microchip or storage in electronic or digital form, because storing the minuta deeds is more practical and does not take up a lot of space, and makes it easier to maintain and search for the minuta archives if one is needed.
\end{abstract}

Keywords: Notary; Deed; Notary Protocol.

\section{INTRODUCTION}

In essence, the position of a notary is a public official assigned by the general power to serve the needs of the community in terms of authentic evidence that provides certainty of civil law relations. So, as long as authentic evidence is still needed by the state legal system, the position of a notary will still need its existence in the community. ${ }^{1}$

\footnotetext{
${ }^{1}$ G.H.S. Lumban Tobing. (1999). Peraturan Jabatan Notaris. Jakarta: Erlangga. p.1
} 
The term notary comes from the word "notarius", which is name given by the Romans whose job was to carry out writing at that time. There is also an opinion which states that the name of the notary comes from the word "Nota Literia", which means a sign or character that states a word. ${ }^{2}$ Notaries in UUJN qualify as public officials, but the qualifications of notaries as public officials are not only for notaries because the Land Deed Making Official (PPAT) is also qualified as a public official and auction official. The granting of qualifications as a public official to an official other than to a notary is contrary to the meaning of a public official himself, because like PPAT only makes certain deeds relating to land with a predetermined type of deed, and auction officials are only for auction. . ${ }^{3}$ Notary is a public official whose sole authority is to make an authentic deed regarding actions, agreements and stipulations required by a general regulation or by an interested party to be stated in an authentic deed, guarantees the certainty of the date, keeps the deed and provides grosse, copy and excerpt. , all of them as long as the making of the deed by a general regulation is not assigned or excluded to other officials or persons. ${ }^{4}$

The notary office is an institution created by the state. Placing a notary as a position is a field of work or duty that is deliberately made by legal regulations for certain purposes and functions (certain authorities) and is sustainable as a permanent work environment. In principle, the authority of a notary is an authority of a general nature, which includes the drawing up of all types of deeds, except those that are not made by a notary public. In other words, officials other than notaries only have the authority to make certain deeds and must be based on the laws and regulations governing them, these prohibitions are intended to guarantee the interests of the public who require notary services.

Notary in carrying out its duties and authority to make deeds which are requested by the parties facing it, the Notary must fulfill 4 (four) elements, namely: 1 . The element of truth, 2. The element of validity, 3. The element of completeness, 4 . The element of clarity. In addition to having the authority to make agreement deeds and other civil legal acts, Notaries also have the authority to keep Notary protocols. As stated in Article 16 Paragraph 1 Letter B and $E$ of the amendment of UUJN, it requires every notary to keep a minimum deed as part of the Notary protocol and requires every Notary to issue a grosse deed, a copy of the deed or an excerpt of deed based on the minimum deed at the request of the parties or heirs of the parties. ${ }^{5}$

The position of a Notary can not always be held by a Notary, this can be seen by the age limit for a Notary in carrying out the duties of the Notary profession. As with Civil Servants, Notaries also recognize the maximum age limit for running. his position as Notary as determined by UUJN. Article 8 paragraph (1) of Act No. 30 Of 2004 states that: a) has died; b). Has reached the age of 65 (sixty five) years; c). Request itself; d) Being spiritually and / or physically unable to carry out the duties of a Notary for more than 3 (three) years; e). Concurrent positions as referred to in Article 3 letter g. " The notary holding the notary protocol has the authority to issue a grosse deed, a copy of

2 Raden Soegondo Notodisoerjo. (1993). Hukum Notariat Di Indonesia Suatu Penjelasan. Jakarta: Raja Grafindo Persada. p. 13.

${ }^{3}$ Habib Adjie. (2009). Sekilas Dunia Notaris \& PPAT Indonesia. Bandung: Mandar Maju.p. 13.

${ }^{4}$ Ibid. p. 21

${ }^{5}$ Herlien Budiono \& Albertus Sutjicipto. (2005). Beberapa Catatatn Mengenai Undang-Undang Jabatan Notaris, Majalah Berita Bulanan Notaris/PPAT, RENVOI No.28/Th.III/September 2005, PT. Jurnal Renvoi Mediatama, Jakarta. 2005. 
the deed or an excerpt of the deed. If the notary receiving another notary protocol accepts a protocol that is 25 (twenty five) years old or more, then the protocol must be submitted to the MPD. Regional Supervisory Council (MPD) which has one of the duties to keep notary protocols aged 25 years or over based on the Regulation of the Minister of Law and Human Rights Number M. HH-06.AH.02.10 69 Of 2009 concerning the Secretariat of the Notary Supervisory Council.

Based on this background, the title was raised: "Duties and Responsibilities of Notaries as Recipients of the Minuta Study Deed Protocol concerning the Implementation of the Submission of the Protocol for Notaries Who Have Retired or Died in the City of Salatiga". This study seeks to answer the problem of the Duties and Responsibilities of Notaries as Recipient of the Minuta Deed Protocol so that it can be implemented effectively and efficiently, obstacles and solutions in implementing the Duties and Responsibilities of Notaries as Recipient of the Minuta Deed Protocol, especially in the city of Salatiga.

\section{RESEARCH METHODS}

The approach method used is empirical law (sociological) because in this study it examines people in the relationship of life in society, so the empirical legal research method can be said to be sociological legal research, namely research that uses empirical facts taken from human behavior, both verbal behavior. obtained through interviews and real behavior through direct observation. ${ }^{6}$ The specification is analytic descriptive research. Legal research is focused on examining the compliance of the community, especially notaries as recipients of duties and responsibilities of notaries as recipients of the Minuta Deed Protocol against a legal norm with the aim of measuring whether or not a legal regulation is effective. In this study the data source consists of primary data obtained by researchers through interviews. and secondary data obtained through literature study.In this study an interactive analysis model was used, In this study, an interactive analysis model and qualitative analysis were used, interactive analysis, namely an analysis model that required three components in the form of data reduction, data presentation, and conclusion / verification using a cycle process. ${ }^{7}$ Qualitative analysis is the interpretation of what is determined and the final conclusion is used logic or systematic reasoning which consists of three main components in the data analysis stage, namely data reduction, data presentation and conclusion drawing.

\section{RESULT AND DISCUSSION}

\subsection{Duties and Responsibilities of a Notary Public as Recipient of the Minuta Study Deed Protocol concerning the Implementation of the Submission of the Protocol for Notary Public who has Retired or Has Died in the City of Salatiga}

The birth of a notary was preceded by the birth of the scribae profession in ancient Rome. Scribae is a scholar whose job is to record notes and minutes of an activity or decision and then make copies of the documents, both public and private. The word notary comes from the word "nota literaria" which means a written sign or character

\footnotetext{
${ }^{6}$ Mukti Fajar ND dan Yulianto Achmad. (2007). Dualisme Penelitian Hukum Normatif \& Empiris. Yogyakarta: Pustaka Pelajar. p. 280.

7 HB Sutopo. (1998). Pengantar Penelitian Kualitatif: Dasar-dasar Teori dan Praktis. Surakarta: Pusat Penelitian Surakarta. p. 35
} 
used to write or describe a sentence conveyed by the speaker. The sign or character in question is a sign used in shorthand (stenographies), which was invented by Marcus Tullius Tiro. ${ }^{8}$ In the Reglement op het Notary in Nederlands Indie or what is commonly called the Regulation of Notary Position in Indonesia, which took effect from 1860 (Stbl. 1860 No. 3) contains the governing rules regarding notary institutions in Indonesia. ${ }^{9}$ Most of the statutory regulations governing the position of a Notary are still based on the statutory regulations of the Dutch colonial era, namely the regulations on the position of Notary as stated in Stbl. 1860 Number 3 which has been amended several times. Last amended in Act No. 33 of 1954 concerning Notary Representatives and Temporary Notary Representatives which was promulgated on November 13, 1954 in the State Gazette of the Republic of Indonesia (LNRI) of 1954 Number 101 and Supplement to the State Gazette of the Republic of Indonesia (TLNRI) Number 700.

Article 1 The law states that a Notary is a public official who has the authority to make authentic deeds and other powers as referred to in this Law, so that when we compare it, there is almost no difference regarding the meaning of Notary in PJN and UUJN. In general, it can be concluded that what is meant by a notary is a public official who is authorized to make authentic deeds regarding all actions, agreements and decisions required by laws and regulations and / or that which is desired by those concerned to be stated in an authentic deed, ensuring certainty of date. making deeds, keeping deeds, providing grosse copies and quotations thereof, all as long as the deeds are drawn up, they are not assigned or excluded to other officials or other people as stipulated by law. As regulated by Article 1868 of the Civil Code in conjunction with Article 1 and Article 15 UUJN) agreements and stipulations that are required by laws and regulations and or those interested in are required to be stated in an authentic deed, guarantee the certainty of the deed making date, keep the deed, provide grosse copies and quotations, all as long as the making of the deed is not assigned or excluded to other officials or other people determined by law. As regulated by Article 1868 of the Civil Code in conjunction with Article 1 and Article 15 UUJN). agreements and stipulations that are required by laws and regulations and / or those interested in are required to be stated in an authentic deed, guarantee the certainty of the date of making the deed, keep the deed, provide a copy of the grosse and the quotation, all as long as the deed is made, it is not assigned or excluded. to other officials or other people determined by law. As regulated by Article 1868 of the Civil Code in conjunction with Article 1 and Article 15 UUJN).

On October 6, 2004, the Notary Position Regulation was declared invalid and on that date Act No. 30 of 2004 concerning Notary Position (hereinafter referred to as UUJN-P) was passed. In 2014 the revision of the UUJN was introduced. This revision of UUJN is only applied to some important articles, which if changes need to be made and subsequently promulgated by Act No. 2 of 2014 concerning Amendments to Act No. 30 of 2004 concerning the Position of Notary (hereinafter referred to as UUJN-P) which promulgated on January 15, 2014 in the State Gazette of the Republic of Indonesia (LNRI) of 2014 Number 3 and Supplement to the State Gazette of the Republic of Indonesia (TLNRI) Number 5491, the Notary in carrying out his position refers to UUJN and UUJN-P.

\footnotetext{
${ }^{8}$ Anke Dwi Saputro. (2008). Jati Diri Notaris Indonesia Dulu, Sekarang dan Di Masa Datang: 100 Tahun Ikatan Notaris Indonesia. Jakarta: PT. Gramedia Pustaka. p. 40-41.

${ }^{9}$ Raden Soegondo Notodisoerjo, Op.cit. p.29
} 
According to Habib Adjie Notary / PPAT in the city of Surabaya said:

"Notary as a position (not a professional or professional position), and any position in this country has its own authority. Every authority must have a law. When we talk about authority, the authority of any official must be clear and firm in the laws and regulations governing the official or position. So that if an official commits an action outside of authority, it is called an act of breaking the law ". 10

Before carrying out his position as a Notary, the Notary shall first pronounce his oath of office as stated in Article 4 paragraph (2) UUJN-P, namely:

"I swear / promise: That I will obey and be loyal to the Republic of Indonesia, Pancasila and the 1945 Constitution of the Republic of Indonesia, the Law on the Position of Notary and other laws and regulations. That I will carry out my position with trust, honesty, thoroughness, independence, and impartiality. That I will maintain my attitude, behavior, and will carry out my obligations in accordance with the code of professional ethics, honor, dignity, and my responsibility as a Notary. That I will keep secret the contents of the deed and the information obtained in the exercise of my position. That I have never been and will not give or promise anything to anyone, either directly or indirectly, under whatever name or pretext. "

No later than 60 days from the oath of office, the Notary is obliged to carry out his position in real terms, submit an official report of the notary's oath / promise of office to the Minister, Notary Public Organization, and the Regional Supervisory Council, then submit the office address, sample signature, initials and imprint or red stamp (testament) of Notary Position to the minister, and other officials responsible for land affairs, Notary organizations, chairman of the District Court, MPD, as well as Buptai / Mayor at the place where the Notary is appointed. Regarding the prohibition of carrying out a position outside the area of office in accordance with Article 17 letter a, it is intended to provide legal certainty to the public and at the same time prevent unfair competition between notaries in carrying out their positions. One of the efforts to prevent this competition, ${ }^{11}$ divided into 3 (three) domains of authority, namely general authority (Article 15 Paragraph (1) UUJN), special authority (Article 15 Paragraph (2) UUJN) and authority which will be determined later (Article 15 Paragraph (3). The general authority of a Notary is regulated in Article 15 Paragraph 1, Act No. 30 of 2004 as amended by Act No. 2 of 2014 concerning the Position of Notary Public, these powers are:

The notary has the authority to make authentic deeds regarding all actions, agreements, and provisions that must be required by statutory regulations and / or those desired by those concerned to be stated in the authentic deed. Guarantee the certainty of the date of making the deed, keep the deed, provide grosse, copy and excerpt of the deed, all that as long as the deed is drawn up, it is not assigned or excluded to other officials or other people as stipulated by law.

Supervision of the performance of Notaries in Regency / City areas is carried out by the Regional Supervisory Council, the Regional Supervisory Council is one of the agencies authorized to carry out supervision, which is intended so that the Notary can be

10 Notary / PPAT Monthly News Magazine, RENVOI No.28 / Th.III / September 2005, PT. Journal of Renvoi Mediatama, Jakarta. 2005. p. 39

${ }^{11}$ Habib Adji. Op.cit. p. 31. 
responsible for what has been done so that errors do not occur which may result in losses. for the client himself or the notary concerned. The Supervisory Council formed by the Minister of Law and Human Rights consists of elements from the government, notary organizations and experts or academics. The Supervisory Council in question is the Regional Supervisory Council, the Regional Supervisory Council and the Central Supervisory Council. In the implementation of Notary supervision in each district / city, there is a Regional Notary Supervisory Council. ${ }^{12}$ In the Decree of the Minister of Law and Human Rights Number. M.39-PW.07.10 of 2004 concerning Guidelines for the Implementation of the Duties of the Notary Supervisory Council, that supervision is providing guidance and supervision both preventively and curatively to Notaries in carrying out their profession as public officials so that Notaries must always improve their professionalism and quality of work, so that they can provide guarantee of legal certainty and protection for Notary service recipients and the wider community. Based on Article 1 point 13 of the Amendment UUJN, it states that the notary protocol is a collection of documents which are state archives that must be kept and maintained by a notary in accordance with the provisions of laws and regulations. The opinion of Tan Thong Kie states that:

The protocol belongs to the public, does not belong to the notary who makes the deeds, and also does not belong to the notary who is assigned / appointed by the Minister of Justice to keep it, someone who keeps documents in the notary protocol generally knows that the protocol is safe in the hands of a notary public.

The protocol in 1602 which is kept as a protocol is a copy of the deed, while the original is given to both parties, so that if it is still needed, the notary can make a copy again which is valid according to law. But in other places, the notary keeps the original deed (minuta akta) as a protocol and a copy of it which is considered legally binding as proof, is given to both parties. ${ }^{13}$ Article 62 of the Amendment UUJN provides an explanation that the notary protocol consists of:

a. Minuta Deed; Minuta deed is the original notary deed which is kept in the notary protocol. In the minuta deed, the original signature, initials and thumbprints of the parties, witnesses and notary are listed.

b. Deed register book or repertorium; The repertorium contains notes on all deeds made by or before a notary, either in the form of a deed or in originali by stating the serial number, monthly number, date, nature of the deed and the names of the parties.

In 1695 it was issued a ban on selling the protocol, without the permission of the board, when a notary was replaced or died. In 1728 and 1729 there were changes regarding the submission of the protocol, the notary who would take over the protocol from another notary who had placed his position would be appointed (aangewezen) in advance by the government, if there was no order as follows:

a. The protocols left by notaries who died and notaries who left Indonesia were sent to the storage building (state archive) for safekeeping.

b. Deed documents are properly tied according to registers and then stored.

12 Op.cit. p. 173.

13 A. Kohar. (1983). Notaris Dalam Praktek Hukum. Bandung: Alumni. p. 3. 
This action is taken for the sake of orderly and orderly implementation of the storage of protocols that are often lost. The death of a notary, apart from leaving problems regarding pending work, of course, will also leave other problems related to the Notary protocol. The notary receiving the notary protocol is not the deed maker of the Notary protocol submitted to him, the notary receiving the protocol from another notary is obliged to keep this deed and is not responsible for the contents of the deed of the notary protocol he receives, the notary recipient is only directly responsible for the notary protocol.

The notary who is appointed as the recipient of the Notary protocol must keep and maintain the Notary protocol properly, like the State archive If later there is a dispute or one related to the Notary protocol that has been submitted to the Notary Public who receives the Notary Protocol, the Notary who receives the protocol must deal with law enforcement officials. The notary receiving the protocol can provide services to clients or the public by issuing a grosse deed, a copy of the deed and an excerpt of the deed of the minuta deed that is part of the Notary protocol that has been submitted to him. Based on Article 62 letter a UUJN it is stated that other notaries who will receive the protocol of notaries who have passed away are notaries appointed by the MPD. Submission of protocols to deceased notaries,

\subsection{Constraints and Solutions in the Duties and Responsibilities of Notary Recipient of the Minuta Notary Deed who has retired or has died in the city of Salatiga}

In the provisions of Article 1 paragraph (8) of Act No. 30 of 2004 concerning the Position of Notary Public, it is stated that the Minuta deed is a document which is a State archive. In Article 1 paragraph (8) of Act No. 2 of 2014 concerning Notary Position, it is stated that the Minuta Deed is the original Deed which includes the signatures of the parties, witnesses and notaries, which are kept as part of the notary protocol. The notary protocol is considered a state archive in Article 1 point 2 of Act No. 43 of 2009 concerning Archives, which explains that archives are records of activities or events in various forms and media in accordance with developments in information and communication technology that are made and accepted by State institutions, local governments. , educational institutions, companies, political organizations, civil society organizations,

The keeping of the Notary Protocol by the notary who holds the protocol is an effort to maintain the legal age of the notary deed as a perfect evidence for the parties or their heirs to be calm about everything contained in the deed. Notary died, but there will still be a notary deed that has a juridical age, and exceeds the notary's own biological age. Article 65 UUJN Substitute Notary Public and Temporary Officer Notary is responsible for any deeds made even though the notary protocol has been submitted or transferred to the notary protocol depositor. According to the provisions of the Article, it means that the notary, Substitute Notary Public and Temporary Officer of the Notary must still be responsible until the last breath. In carrying out its duties, the Notary in the City of Salatiga experiences several obstacles, including:

a. Lack of sufficient and adequate space, due to the large number of protocols that must be accepted, it is not uncommon for the notary receiving protocol to lack a place to store due to limited office space; 
b. The notary receiving the Protocol often finds it difficult to transport the Notary Protocol if the notary receiving the Protocol has moved offices;

c. The protocol provided to the receiving notary public directly adds to the risk and responsibility.

d. The protocol given to the recipient notary directly will add to the costs for treatment and others.

The above matter is one of the reasons a notary does not want to accept protocols from other notaries because they feel "bothered". According to the authors, based on research at the Land Office in Klaten Regency, the following authors present several solutions for Notaries who receive the minimum deed protocol, including:

a. Keep the minimum deed protocols neat and orderly, this is to avoid the occurrence of lost or damaged protocols.

b. Storage of deed minuta in the form of soft copy, storage in the form of microchip and storage in digital form so that the storage of deed minutes is more practical and does not take up a lot of space, and makes it easier to maintain.

c. Laws and regulations should be made that regulate the legality of the notary protocol storage in electronic or digital form. Thus, the evidentiary strength of archives and documents in notary's protocol in electronic and digital form can be juxtaposed or cannot be equated with authentic evidence with paper evidence without any other evidence such as witness testimony or expert witnesses.

With the transfer of the notary protocol from conventional (paper based) to electronic (digital based), the notary profession receiving the Minutaakta protocol in carrying out its authority and obligation to store archives and documents in the notary protocol becomes more effective and efficient, because the documents in electronic form, it is easy to find again if there are clients who need these documents for a long time, besides that the notary's work is more efficient because it is more economical because it requires a lot of paper and saves time for notaries in entering and storing these documents.

\section{CLOSING}

\subsection{Conclusions}

Based on the description above, the conclusions in this study are:

1. Implementation of Duties and Responsibilities of a Notary as Recipient of Duties and Responsibilities of a Notary Public as Recipient of the Minuta Protocol, especially in the City of Salatiga, namely if the Notary applies for leave and turns out to be dead while carrying out the leave, his / her job duties will be carried out by a substitute Notary as a Temporary Notary Officer for a maximum of 30 (thirty) days from the date of the Notary's death, this is in line with the content of Article 35 paragraph 3 UUJN-P. Notary who dies before the leave ends, his / her job duties will be carried out by a substitute notary as a notary's temporary official without being appointed as a Notary's Temporary 
Officer. The Temporary Officer of Notary Public can carry out what is within their authority within 30 days from the date of the Notary's death and can make deeds in his own name and has a Notary Protocol. The notary receiving the protocol is not responsible for any problems arising from the protocol submitted to him. The notary receiving the protocol can only provide, show, or notify the contents of the deed, gross deed, copy of the deed or an excerpt of the deed to people with direct interest in the deed, heirs, or people who obtain rights, unless otherwise stipulated by laws and regulations.

2. The obstacles faced in the Implementation of Duties and Responsibilities of Notaries as Recipients of Duties and Responsibilities of Notaries as Recipients of the Minuta Protocol, especially in the City of Salatiga, are:

a. Lack of sufficient and adequate space owned by the notary receiving the protocol, due to the large number of protocols that must be accepted, it is not uncommon for the notary receiving protocol to lack a place to store due to limited office space.

b. The notary receiving the protocol often finds it difficult to transport the Notary Protocol if the notary receiving the Protocol has moved offices.

c. The protocol given to the receiving notary public directly adds to the risk and responsibility as well as to increase the costs for treatment and others.

\subsection{Suggestion}

1. In connection with the storage of the protocol by the receiving notary public, it is better if the minimum deed is stored in soft copy, storage in the form of microchips and storage in electronic or digital form, as an example of storage on the cloud or google drive so that the storage of deeds is more practical and does not take up much space, as well as making it easy to maintain and search for minuta archives if one is needed.

2. There should be written regulations that further regulate that protects the notary protocol giver, especially those who are retired or on leave, against the transfer of the protocol he made while still on duty to the notary who received the protocol in the event of loss or damage in the future in the hands of the notary protocol holder. This is intended to provide legal protection for the notary protocol giver, because after switching, the giver cannot be responsible for any conditions that occur in the notary protocol.

3. The notary who receives the protocol should also be given specific and written rules regarding the obligations, responsibilities and rights obtained as a protocol recipient. Thus the recipient can feel more responsible for the mandate given. So that when a situation occurs where the protocol it is holding is lost or damaged, the recipient of the protocol knows what steps must be taken to solve the problem.

4. It is expected that the Notary Public, Substitute Notary Public, Temporary Notary Officer, Notary holder of the protocol and the Regional Supervisory Council in carrying out their duties are obliged to keep and maintain the notary protocol indefinitely as long as the notary protocol is required by the client or related parties and / or until there are regulations regarding notary protocol 
storage time limit. The Notary Protocol is a state archive that must be kept and maintained by a notary public. However, the archival regulation does not regulate the notary protocol as stipulated in the UUJN even though the notary protocol is a state archive.

5. The re-inauguration of a Notary Public as a Notary Public Officer, according to the author, this right is necessary because the notary protocol as a state archive is also not regulated in detail in the Law on Notary Position, for example relating to policies, guidance and management of notary protocols. This raises legal uncertainty for notaries in keeping and maintaining notary protocols. According to the viewpoint of academics, there must be an inauguration as a Notary Public as Temporary Officer to replace the Notary who died while on leave. while in terms of implementation, in this case the Minister represented by the Regional Office who inaugurated,

6. Regulations should be made regarding biological accountability (notary age) as an official with a time limit, so that when a Notary is no longer in office and no longer has authority on him, there is no need to think about the accountability and authority of the minimum deed they have made.

\section{REFERENCES}

A. Kohar. (1983). Notaris Dalam Praktek Hukum. Bandung: Alumni

Anke Dwi Saputro. (2008). Jati Diri Notaris Indonesia Dulu, Sekarang dan Di Masa

Datang: 100 Tahun Ikatan Notaris Indonesia. Jakarta: PT. Gramedia Pustaka

G.H.S. Lumban Tobing. (1999). Peraturan Jabatan Notaris. Jakarta: Erlangga

Habib Adjie. (2009). Sekilas Dunia Notaris \& PPAT Indonesia. Bandung: Mandar Maju

(2008). Hukum Notaris Indonesia (Tafsir Tematik Tehadap UU No.30 Tahun 2004 Tentang Jabatan Notaris ). Bandung: PT.Refika Aditama

HB Sutopo. (1998). Pengantar Penelitian Kualitatif: Dasar-dasar Teori dan Praktis. Surakarta: Pusat Penelitian Surakarta.

Herlien Budiono \& Albertus Sutjicipto. (2005). Beberapa Catatatn Mengenai UndangUndang Jabatan Notaris, Majalah Berita Bulanan Notaris/PPAT, RENVOI No.28/Th.III/September 2005, PT. Jurnal Renvoi Mediatama, Jakarta. 2005.

Mukti Fajar ND dan Yulianto Achmad. (2007). Dualisme Penelitian Hukum Normatif \& Empiris. Yogyakarta: Pustaka Pelajar.

Raden Soegondo Notodisoerjo. (1993). Hukum Notariat Di Indonesia Suatu Penjelasan. Jakarta: Raja Grafindo Persada 